\title{
The Landscape and Nature of the Cyclops in Campanian Wall-Painting
}

\author{
Abigail Walker
}

Scholarship on Campanian wall-painting has expressed consistent interest in the appearance of landscape paintings at the end of the first century BCE and their continued presence in domestic decoration throughout the first century CE. As such, landscape has been inserted into a series of grand narratives that relate it to the painted corpus and Roman culture at large. Analysed as part of the wider chronology, it has been a strong indicator of both the influence of the Hellenistic tradition and the rise of Roman innovation. ${ }^{1}$ Paintings that show an unfettered natural abundance and which idealise country life have been aligned with the Augustan evocation of the Golden Age and Rome's simple origins. ${ }^{2}$ Landscape has been observed for its establishment of social frameworks within the villa or townhouse: issues such as the patron's verdant luxury and otium, their civilising power over nature, and the extension of their estate beyond the solid walls of the home, have all reflected the key role that landscape played in the broader social hierarchical implications of the domestic sphere. ${ }^{3}$ Finally, landscape has been the subject of various modern

1 See, for example, C. Dawson, Romano-Campanian Mythological Landscape Paintings (Yale 1944), 50-79; 136-180; K. Schefold, 'Origins of Roman landscape painting', ArtB 42 (1960), 87-96; J.-M. Croisille, Paysages dans le Peinture Romaine (Paris 2010), 19-32. See also R. Ling, 'Studius and the beginning of Roman landscape painting', JRS 67 (1977), 1-16, for the key discussion of the first supposed Roman landscape artist.

2 See, for example, B.A. Kellum, 'The construction of landscape in Augustan Rome', ArtB 76 (1994), 211-224; S. Carey, 'A tradition of adventures in the imperial grotto', GaR 49 (2002), 44-61; Croisille 2010, op. cit. (n. 1), 138-139.

3 See, for example, M. Rostovtzeff, 'Pompeianische Landschaften und römische Villen', JdI 19 (1904), 103-126; B. Bergmann, 'Painted perspectives of a villa visit: landscape as status and metaphor', in E.K. Gazda (ed.), Roman Art in the Private Sphere (Ann Arbor 1991), 49-70; N. Purcell, 'The Roman villa and the landscape of production', in T.J. Cornell and K. Lomas (eds.), Urban Society in Roman Italy (London, New York 1995), 151-18o; J.C. Reeder, The Villa of Livia Ad Gallinas Albas: A Study in the Augustan Villa and Garden (Providence 2001); D. Spencer, 'Roman landscape: culture and identity, Greece and Rome', New Surveys in the Classics 39 (Cambridge 2010), 62-134; 135-171; M. Zarmakoupi, Designing for Luxury on the Bay of Naples: Villas and Landscapes (c. 100 BCE-79 CE) (Oxford 2013), 122-140; S. Ellis, 'Art 
catalogue volumes which have sought to offer an overview of the genre at large, the categories therein, and their chronological developments. ${ }^{4}$

These are the sorts of grand - chronological, political, and social - narratives that have guided much of the study of Campanian landscape painting in the early Roman Empire. Such analyses are of course key for contextualising landscape and placing it within the corpus at large. This paper, however, aims to step away from this broad picture and consider the individual and more case-specific potential that landscape had within the painted corpus. For this close analysis, I take a mythological case study, namely that of the Cyclops, Polyphemus. By focusing in on the use of landscape within this painted narrative, my approach considers the concept of landscape as an important form of and tool for representation in the early Roman Empire.

In the case of Polyphemus, the concept of landscape as representation works on several levels. Firstly, the landscape of the Cyclops reflects many of the themes present in the narrative; it will show how the landscape possesses the power to represent ideas such as Polyphemus' heritage, his wild characterisation, and his incompatible courtship of Galatea. The landscapes will, in Newby's words, be seen to act "as agents within the narrative presented." Furthermore, this paper will also consider the ways in which Polyphemus' visual landscape tradition engages with the issue of literary representation: it will investigate how the landscape could carry certain generic associations and, therefore, mediate between visual and textual representational forms.

My argument here is that the representation of landscape plays an active role in the interpretation and depiction of Polyphemus, the ambiguous nature of his character, and the myths and literary tradition which surround him. Polyphemus was a pastoral shepherd who fell hopelessly in love with the beautiful sea-nymph, Galatea. But he was also the savage monster who trapped Odysseus and his men in a cave and ate several crewmen. This paper will investigate how the landscape in Campanian paintings of the Cyclops was key to depicting Polyphemus' ambiguity. It will exemplify not only landscape's power of representation, but also its ability to reflect consciously on the Cyclops' own representational tradition.

in the Roman town houses', in B. Borg (ed.), A Companion to Roman Art (Malden and Oxford 2015), 375-379.

4 For some notable examples of these catalogue-type analyses see Dawson 1944, op. cit. (n. 1); W.J.T. Peters, Landscape in Romano-Campanian Mural Painting (Assen 1963); Croisille 2010, op. cit. (n. 1).

5 Z. Newby, 'The aesthetics of violence: myth and danger in Roman domestic landscapes', ClAnt 31 (2012), 349-389, esp. 355 . 
There are twenty-one painted panels identified as Polyphemus and Galatea and one which depicts the Cyclops with an epic hero. Twenty of these paintings were found in the Campanian region, mostly Pompeii, but also Herculaneum and the Villa at Boscotrecase, with the other two from Rome and Assisi. ${ }^{6}$

The paintings have generally been divided up into compositional categories: ${ }^{7}$ panels on a dominant landscape background (known as 'mythological landscape paintings' ${ }^{8}$ ); those which show Polyphemus in letter correspondence; and a third group which depicts the successful sexual culmination of Polyphemus' courtship attempts. I will re-focus these categories around their landscape representation, an approach which, although resulting in similar groupings, highlights the unity and continuity of the landscape throughout the corpus. By analysing the scenes by the landscape, we can also incorporate panels, such as the epic hero example, which have so far appeared to be outliers from these figure-focused compositional groups.

My main source of evidence here is Pompei: pitture e mosaici (hereafter $P P M)$, with additions from other Campanian examples, such as Herculaneum and the surrounding villas. ${ }^{9}$ It should be noted that I have included here panels for which we only have modern reproductions. I acknowledge that these reproductions are somewhat problematic as evidence which is now second-hand; however, this evidence is key for as full a picture of the corpus as possible and, it should be remembered, was intended originally to serve as a record. I will be wary of making arguments regarding the specific minutiae of these images but will use their composition and content as insights to inform my argument.

6 The reader should assume that any painting being discussed is from Pompeii unless stated otherwise.

7 J. Hodske, Mythologische Bildthemen in den Häusern Pompejis: Die Bedeutung der zentralen Mythenbilder für die Bewohner Pompejis (Ruhpolding 2007), 196-199; M. Squire, Image and Text in Graeco-Roman Antiquity (Cambridge 2009), 306-321.

8 Some key studies of 'mythological landscape paintings' as a genre include Dawson 1944, op. cit. (n. 1); Schefold 196o, op. cit. (n. 1), 87; 89; R. Ling, Roman Painting (Cambridge 1991), 113-118; B. Bergmann, 'Rhythms of recognition: mythological encounters in Roman landscape painting', in F. de Angelis and S. Muth (eds.), Im Spiegel des Mythos: Bilderwelt und Lebenswelt (Wiesbaden 1999), 81-107, esp. 81-99; Hodske 2007, op. cit. (n. 7), 97-98; Croisille 2010, op. cit. (n. 1), 42; Newby 2012, op. cit. (n. 5), 373-380.

9 For discussion of the Herculaneum panels see Squire 2009, op. cit. (n. 7), 313-314; 318. For a specific focus on the Boscotrecase paintings see P.H. von Blanckenhagen and C. Alexander, The Augustan Villa at Boscotrecase (Mainz 1990, 2nd ed.), esp. 28-33 for Polyphemus and Galatea. Credit must also go to Hodske 2007, op. cit. (n. 7), 197 and K. Lorenz, Bilder machen Räume: Mythenbilder in pompeianischen Häusern (Berlin and New York 2008), 202 for drawing my attention to the Caccia Antica peristyle panel. 
First, I will return to the so-called 'mythological landscape paintings' where Polyphemus is shown, on a landscape which dominates the panel, singing to Galatea; but let us review here more specifically the depicted setting. Polyphemus is often shown on a central rocky outcrop, which may include sacred or villa structures and is surrounded by a profusion of sea and sky, on which Galatea floats (the Casa del Sacerdos Amandus [1.7.7]; the Casa del Marinaio [7.15.2]; the Casa di Dido ed Aeneas [9.6,d-e]; the Villa at Boscotrecase). In the panel found in Rome, from the Casa di Livia on the Palatine, the Cyclops has left his central rocky promontory and ventured into the waters themselves.

In some examples of these landscape-dominated panels, Polyphemus does not take the central position and the image is instead divided into two, with the sea (and Galatea) on one side and the land (and Polyphemus) on the other (the Casa dei Vasi di Vetro [6.5.5]; Casa dei Capitelli Colorati [7.4.31;51]; Casa di Properzio [9.7.12], Assisi, where masks are used to depict the lovers). The sea, here, can take a variously dominant position, with the panel sometimes divided in half or sometimes favouring the seascape over the land. One remaining example, the painting from the peristyle of the Casa della Caccia Antica (7.4.48), inverts the landscape composition in panels such as the one from Boscotrecase: it places the sea at a central position, surrounded instead by the land.

In the second group of paintings, we still see both land and sea depicted, but the prospect focuses in more closely to the figures; we see just a glimpse of the rocky promontory and the water which laps at its shore. This type of landscape is almost exclusively used for the letter-type of narrative, where we see the Cyclops perched on the edge of the landscape and Cupid approaches, by sea, on a dolphin, adopting the marine iconography of the otherwise absent nymph (Casa 5.2,d; Caupona della Via di Mercurio [6.10.1]; Casa di Laocoonte con annessi taberna e panificio, (hereafter just Casa di Laocoonte) bottega (c) [6.14.28;33]; Casa di Marcus Lucretius, cubiculum (7) [9.3.5;24]; an unprovenanced panel from Herculaneum [MNN8984])..$^{10}$ The other panel that we can include in this group, which is not of the letter-type, is the panel from tablinum (k) of the Casa di Laocoonte. Again, this panel shows Polyphemus standing on the rocky landscape but, instead of carrying either Galatea or Cupid, the sea marks the arrival of a ship and crew. This is the only panel where we see an epic hero depicted with the Cyclops, variously identified as Odysseus or,

10 There are issues with the reproduction and restoration with a few of these panels; however, the panel from Herculaneum is well-preserved and both the seated position of Polyphemus and the arrival of Cupid by dolphin in the less well-preserved panels adhere to the expected pattern. 
more often, Aeneas. ${ }^{11}$ The damaged state of this painting makes interpreting the landscape somewhat problematic; however, the arrival of the ship indicates at least the suggestion, but probably to some extent the depiction, of the sea. Furthermore, the fragmented view of the ship also confirms that there was a landscape form in the foreground, partially blocking it. It seems likely, then, that we have a part-land- and part-seascape.

Finally, we have panels where the land, rather than the sea, dominates, and Galatea has come ashore. Although the sea is almost entirely absent in these panels, in three from this group it is nonetheless still represented through the sea nymph's attribute, the aquatic leaf (two unprovenanced panels from Herculaneum [MNN8983 and MNN9244], and the Casa di Marcus Lucretius, cubiculum (5) $[9 \cdot 3.5 ; 24])^{12}$ Despite not painting the sea itself, the artist has still found an alternative means of noting its presence. Other examples where Galatea has come ashore depict an erotic narrative where Polyphemus and Galatea are shown in sexual embrace, either with or without her aquatic leaf (Casa della Caccia Antica, area (15) [7.4.48]; Casa delle Pareti Rosse [8.5.37]; and, from compositional parallels with the Casa della Caccia Antica panel, presumably also the Casa del Gallo II [9.2.10]). The lack of even her attribute, in the Pareti Rosse panel, as an allusion to the sea, highlights Galatea's unexpected abandonment of her watery realm.

Although we see variety in the narratives depicted - Polyphemus' courtship song, letter correspondence, sexual intercourse, and the arrival of an epic hero - the landscape of sea and terrain remains consistent, if depicted to a greater or lesser extent. We see the Cyclops seated on a rocky coastline, promontory or outcrop, and the sea present either literally, suggestively (through Galatea's aquatic attribute) or, indeed, conspicuously absent.

The rest of this paper will be divided into two main parts. The first part, The Idyllic Grove and the Epic Cave, considers the idealised, pastoral iconography of the Polyphemus panels and the effect of his presence on such a landscape. The second part, An Elemental Affair, will consider the distinction set up in the paintings between land and sea. Finally, I will offer some concluding thoughts about what my approach to this case study of Polyphemus can tell us about the idea of landscape in the early Roman Empire.

11 See M. Cadario, 'Signum periturae Troiae, gli "altri Laocoonti" nella pittura Romana', G. Bejor (ed.), Il Laocoonte dei Musei Vaticani: 500 anni dalla scoperta (Milan 2007), 45-103, esp. 56-61. 
With the exception of one panel, the Campanian paintings of Polyphemus depict his love affair with Galatea, a narrative brought to focus in Theocritus' pastoral poetry (Idyll 11). ${ }^{13}$ However, by Theocritus' Hellenistic period, the Cyclops was already part of a literary tradition that stretched back to Homer's epic, the Odyssey. As we will see, both of these genres - epic and pastoral - play a vital role in the Polyphemus depictions found in Campanian wall-painting; rather more crucially here, though, they also have landscape associations which were used in the myth's representation. The absurdity and comedy of the cannibalistic, monstrous Cyclops of Homer's epic placed, via Theocritus, in a pastoral environment and characterised as a pathetic, lovelorn shepherd, was clearly not lost on the first-century audience. In fact, this juxtaposition is playfully employed, in a first-century CE context, in Ovid's Metamorphoses, where the pastoral Cyclops sings a monstrous courtship song to the nymph. ${ }^{14}$ The contradictory undercurrents implicit in this generic interplay were constantly employed in the visual representation of the Cyclops and the landscape in which he was placed.

In 1999, Bettina Bergmann published an article that convincingly argued for the compositional parallels evident between mythological images and non-narrative landscape panels, often called 'sacro-idyllic'. ${ }^{15}$ She identifies "patterns which [...] stimulated certain rhythms of recognition in the viewers" between anonymous landscape panels and their mythological cousins: ${ }^{16}$ "There, in rustic wooded sanctuaries or along rocky coasts, anonymous figures go about their daily activities of fishing or offering at a shrine. In some scenes, however, the characters carry distinctive attributes and engage in specific, dramatic actions that identify them as mythological."17

A comparison of the Polyphemus and Galatea panel from the Villa at Boscotrecase (fig. 17.1) with one of the non-narrative panels (fig. 17.2) from the

13 It is widely accepted that Theocritus used Philoxenus as a source, who first told the story of Polyphemus in love (see J.H. Hordern, 'The Cyclops of Philoxenus', CQ 49 (1999), 445455, esp. 445; J.H. Hordern, 'Cyclopea: Philoxenus, Theocritus, Callimachus, Bion', cQ 54 (2004), 285; 285-293, esp. 288-29o; Squire 2009, op. cit. (n. 7), 301-302). The focus of this earlier text, however, seems still to have been the interaction between Odysseus and the monstrous Cyclops. It is not unrealistic, therefore, to argue that it was Theocritus, in the pastoral genre, which truly revolutionised Polyphemus' love affair from mere plot device in Philoxenus (a means by which Odysseus could trick the monster) to full thrust of the narrative.

14 Ov. Met. $13 \cdot 789-869$.

15 Bergmann 1999, op. cit. (n. 8).

16 Bergmann 1999, op. cit. (n. 8), 81.

17 Bergmann 1999, op. cit. (n. 8), 82. 


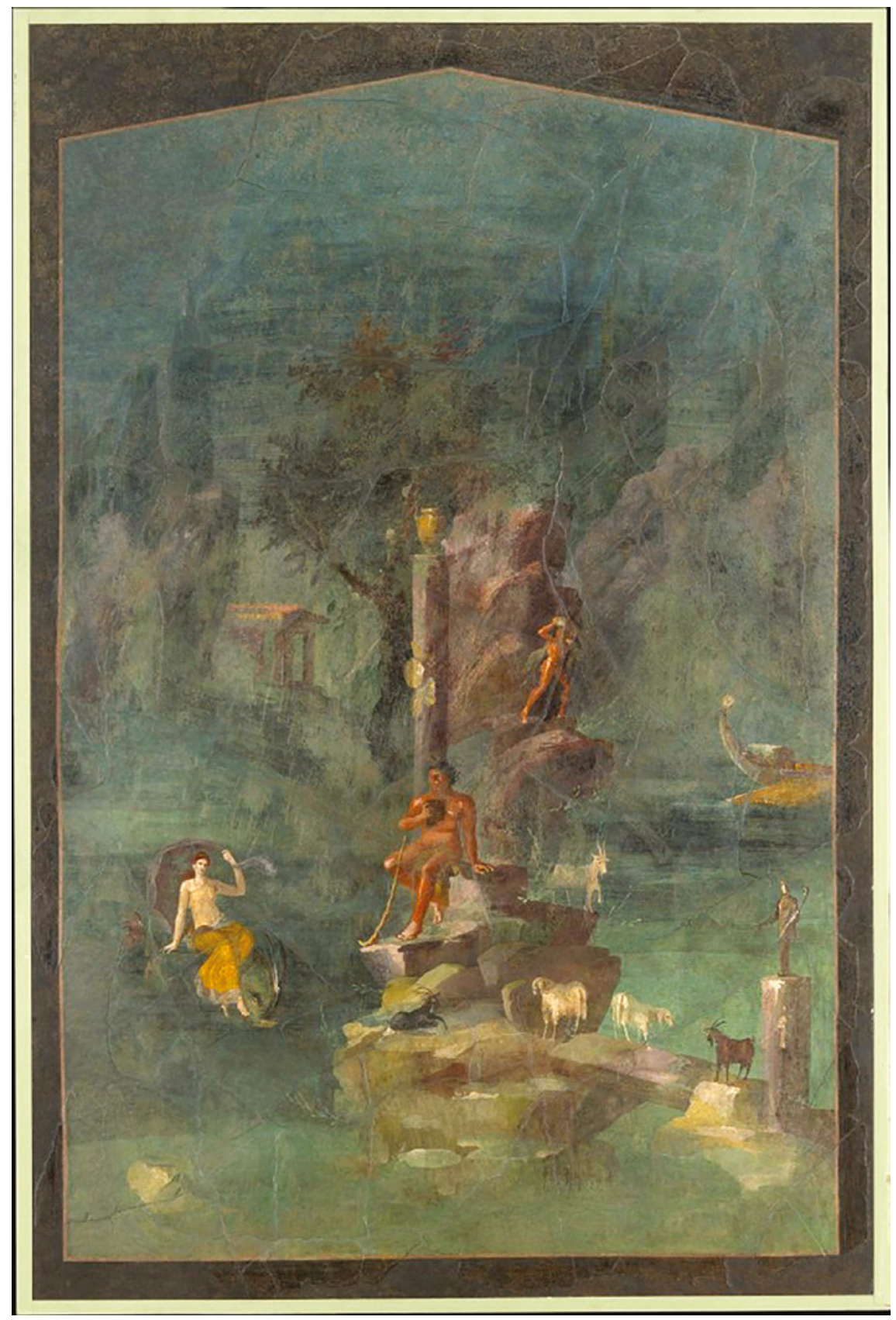

FIGURE 17.1 Panel from the Villa at Boscotrecase PHOTO COURTESY OF THE METROPOLITAN MUSEUM OF ART ROGERS FUND, 1920, 20.192.17 


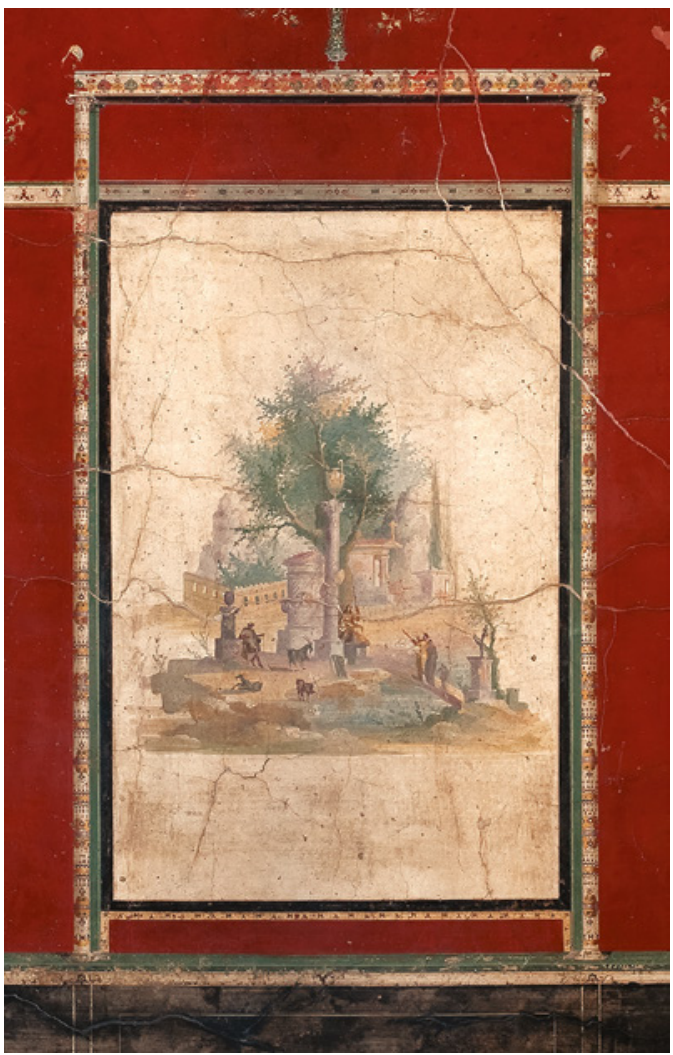

FIGURE 17.2 Panel from the Villa at Boscotrecase PHOTO BY CONCESSION OF THE MINISTERO PER I BENI E LE ATTIVITÀ CULTURALI E PER IL TURISMO - MUSEO ARCHEOLOGICO NAZIONALE DI NAPOLI

so-called Red Room of the same villa is exemplary of such "rhythms of recognition". In these panels, we see exactly the same column, topped with a vessel and adorned by a shield (in almost exactly the same position), with a large central tree behind. The rocky promontory of the Polyphemus panel creates a similar, tapering, composition as the architectural monuments in the anonymous landscape. We even see a bridge, with a cult statue, in the same place in both scenes, and a seated central figure with additional observers and goats. Water runs in a channel in the foreground of both and there is a building in the background of the Polyphemus painting, which echoes the structure on the opposite side in the anonymous panel. Galatea leans back on one arm, just as the figure to the left of the column in the Red Room; their postures and compositional placement are remarkably analogous. Bergmann argues that 


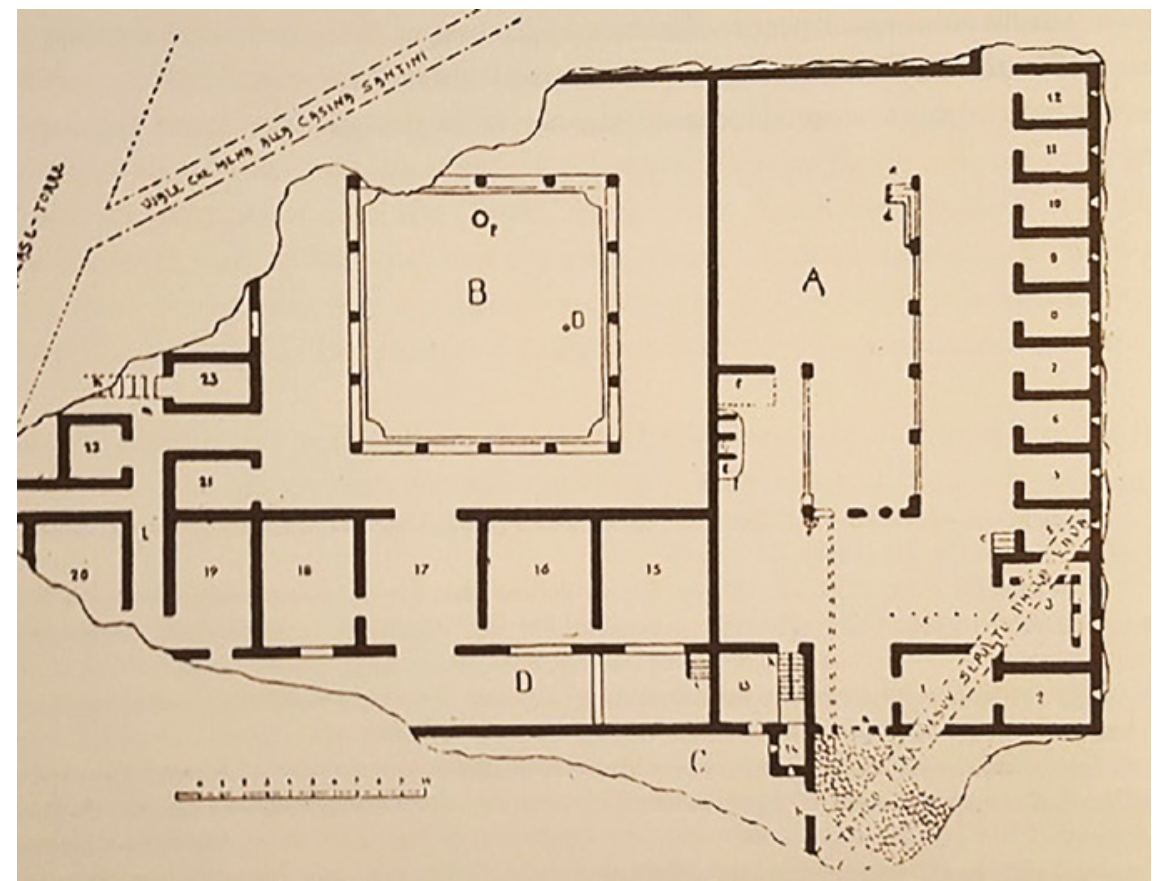

FIGURE 17.3 Villa at Boscotrecase floorplan PHOTO COURTESY OF P.H. VON BLANCKENHAGEN AND C. ALEXANDER, THE AUgUStan Villa AT boscotrecase, (MAINZ 1990, 2ND ED.), 4

this type of anonymous, idealised landscape painting, such as we find in the Red Room, is "the classic locus amoenus characterized by Virgil."18 Indeed, it has been well-attested in modern scholarship that such paintings evoked the type of rural, peaceful, and pious places that were employed and idealised by pastoral poets. ${ }^{19}$ The Polyphemus panel (room 19) clearly asks the viewer to recognise its pendant relationship with the idyllic landscape just a few rooms away (room 15; see fig. 17.3 for the floorplan), and to acknowledge the formula of landscape representation evoked between the two images.

18 B. Bergmann, 'Exploring the grove: pastoral space on Roman walls', in J.D. Hunt (ed.), The Pastoral Landscape (Washington 1992), 20-46, esp. 32.

19 For discussions of 'sacro-idyllic' paintings as idealised rural life see Schefold 1960, op. cit. (n. 1), 9o; Peters 1963, op. cit. (n. 4), 191; E.W. Leach, 'Sacral-idyllic landscape painting and the poems of Tibullus' first book', Latomus 39 (1980), 47-69; Bergmann 1992, op. cit. (n. 18), 34; E.R. Knauer, 'Roman wall paintings from Boscotrecase: Three studies in the relationship between writing and painting', $M M J 28$ (1993), 13-46, esp. 18 and 20; Croisille 2010, op. cit. (n. 1), 45 . 
In many ways, then, Polyphemus, depicted in his pastoral narrative and with pastoral attributes such as a shepherd's staff and panpipes, seems well suited to such a landscape. ${ }^{20}$ And yet, any viewer with even a basic knowledge of the mythological tradition of the Cyclops should know better than to trust the peace and security of the idyllic scene. After all, Polyphemus was a cannibalistic monster of epic proportions, who acts wildly and violently against the crew of Odysseus who enter his domain. It is striking, then, that Bergmann's "rhythms of recognition" draw a parallel, at Boscotrecase, between Polyphemus and the deity seated in the same position on the Red Room panel. The Cyclops is represented as no ordinary pastoral shepherd-bard but is elevated to the status of a rustic god in a sacred landscape. He is seated in an empowered position, reserved usually for the deity or shrine. The pastoral role of the Cyclops is exaggerated here to numinous and 'epic' proportions.

This is made even more explicit by this panel's direct reference to the epic storyline. In the Boscotrecase painting, we also see Polyphemus throwing a boulder at the fleeing ship of Odysseus, a narrative enacted not only in the same panel as the pastoral story but staged on the very same landscape. In the example from the Casa del Sacerdos Amandus (fig. 17.4), too, we see a ship encroaching on the scene. This intrusion alludes to the epic sea-born adventures of - perhaps deliberately ambiguously - both Homer's Odyssey and Virgil's Aeneid (for in the latter we revisit the Odyssean Polyphemus through the witness account of an abandoned crewman). ${ }^{21}$ Indeed, the approaching ship also reminds us of the only extant epic painting of Polyphemus from the Casa di Laocoonte (fig. 17.5), where again the ship intrudes upon the pastoral idealism of the shepherd Cyclops, complete with panpipes and staff.

We especially see the intrusion of Polyphemus' epic and wild nature and narrative on the pastoral idyll through the suggestion of the cave throughout the corpus. In discussion of the grotto-triclinium of Sperlonga - which also features the Cyclops in his epic story - de Angelis argues that the "association of caves and underground recesses with uncanniness is constant with the inherently frightening dimension of the represented episodes."22 In the

20 For more on the panpipes or syrinx see also Hordern 2004, op. cit. (n. 13), 289; A. Barchiesi, 'Music for monsters: Ovid's Metamorphoses, bucolic evolution, and bucolic criticism', in M. Fantuzzi and T. Papanghelis (eds.), Brill's Companion to Greek and Latin Pastoral (Leiden and Boston 2006), 403-425, esp. 409; Cadario 2007, op. cit. (n. 11), 56; 59-6o; D. Creese, 'Erogeneous organs: the metamorphosis of Polyphemus' "syrinx" in Ovid, Metamorphoses 13.784', cQ 59 (2009), 562-577, esp. 566-571.

21 Virg. Aen. 3.613-674.

22 F. De Angelis, 'Roman art and myth', in Borg 2015, op. cit. (n. 3), 569-584, esp. 576 . See also H. Lavagne, Operosa Antra: recherces sur la grotte à Rome de Sylla à Hadrien (Paris 1988) for an in-depth analysis of the cave in the Roman cultural imagination. 


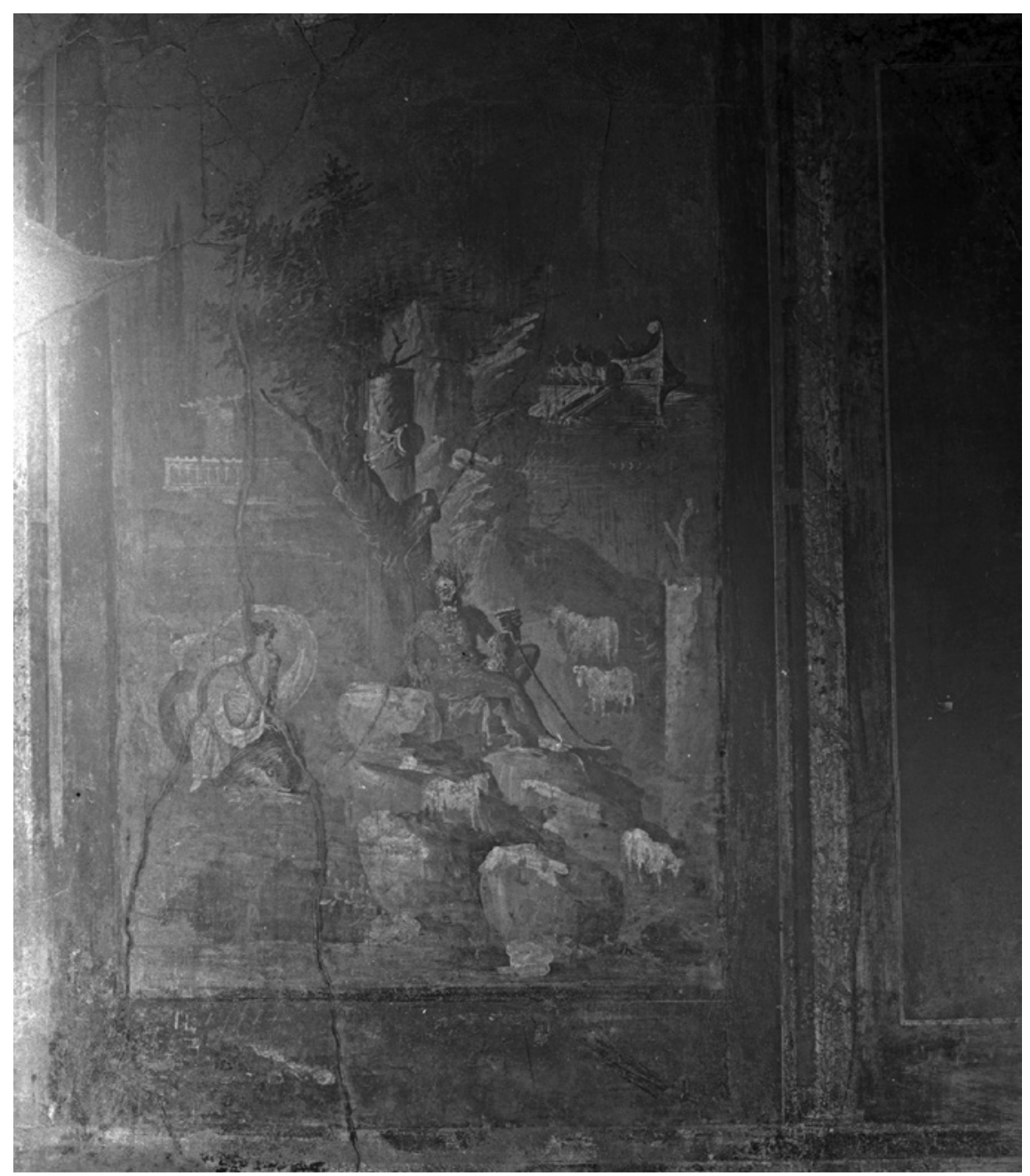

FIGURE 17.4 Panel from the Casa del Sacerdos Amandus PHOTO COURTESY OF PROFESSOR MICHAEL SQUIRE

context of the Cyclops, therefore, the cave already has significant implications as the stage upon which the gory adventure of the Odyssey was set. Although Polyphemus is not shown in his cave in Campanian wall-paintings, I propose that it is in fact not absent, for rocks and rocky landscapes persist throughout the corpus. Two examples are particularly worth highlighting. The first is the panel from the Casa di Laocoonte (fig. 17.5) which shows Polyphemus with epic heroes. Although, as discussed above, the ship here does imply a marine setting, the overwhelming impression of the painting's landscape is undoubtedly mountainous. The wall of rock that faces the viewer denies any 


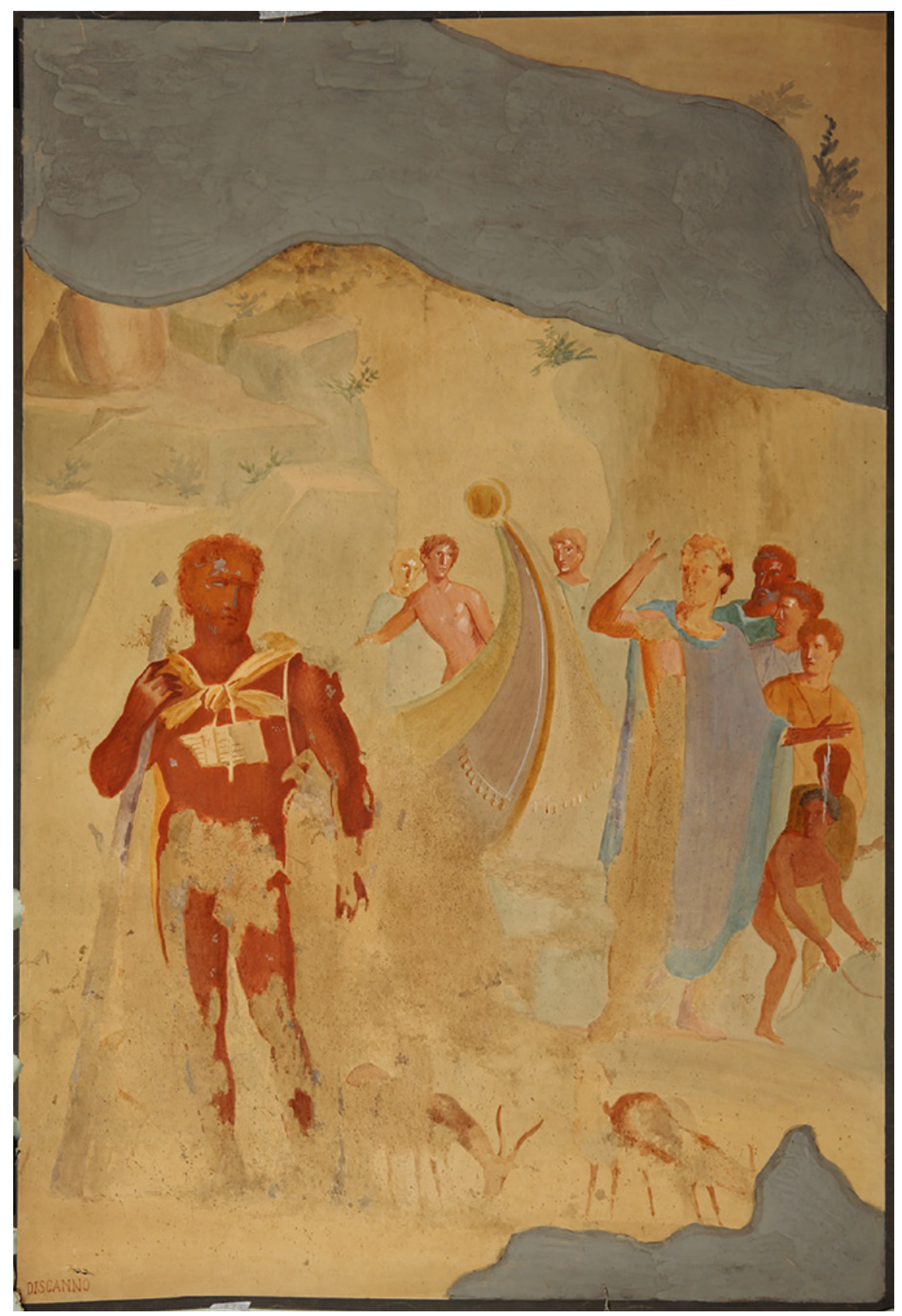

FIGURE 17.5 Panel from the Casa di Laocoonte con annessi taberna e panificio PHOTO BY CONCESSION OF THE MINISTERO PER I BENI E LE ATTIVITÀ CULTURALI E PER IL TURISMO - MUSEO ARCHEOLOGICO NAZIONALE DI NAPOLI 


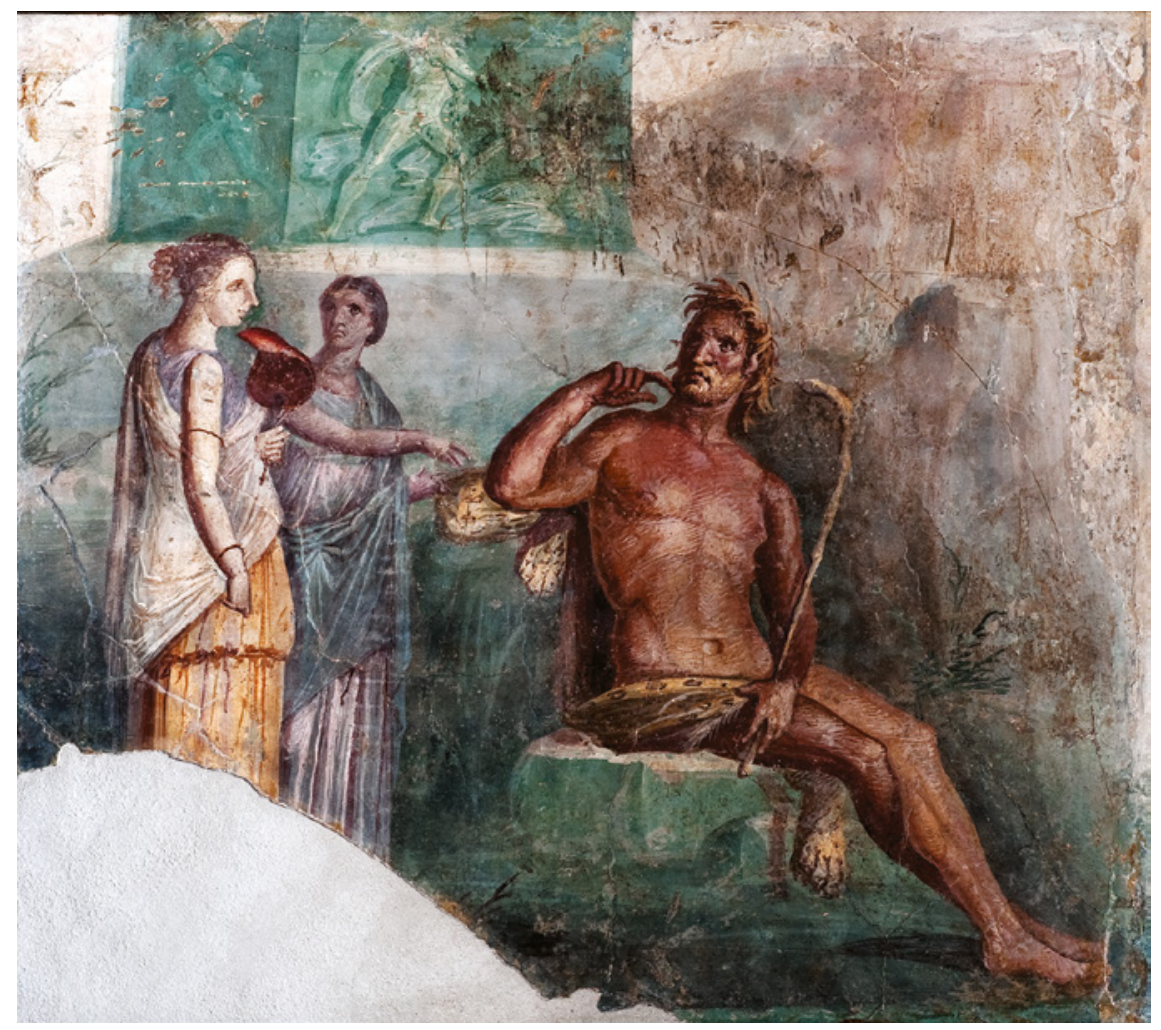

FIGURE 17.6 Unprovenanced panel from Herculaneum, MN8983 PHOTO BY CONCESSION OF THE MINISTERO PER I BENI E LE ATTIVITÀ CULTURALI E PER IL TURISMO - MUSEO ARCHEOLOGICO NAZIONALE DI NAPOLI

sense of spatial depth, apart from the small aperture through which the ship approaches; instead, the rockface encloses and dominates the image. The other example is panel MNN8983 from Herculaneum (fig. 17.6), where, instead of a mountainous backdrop, the stone has been shaped into an architectural form, carved with relief decoration. We can only see part of the sculpted image, however it clearly shows a man lunging forward with a spear, a composition which is allusive of the 'Blinding of Polyphemus' motif that can be found throughout Greco-Roman antiquity, most contemporaneously in the sculpture at Sperlonga. ${ }^{23}$ The cave stages the blinding of Polyphemus, just as the rock provides the material for its representation in the Herculaneum panel. The representative power of the cave in the Polyphemus narrative, therefore, colours the use of rock and loads it with interpretive potential.

23 Squire 2009, op. cit. (n. 7), 325-329. 


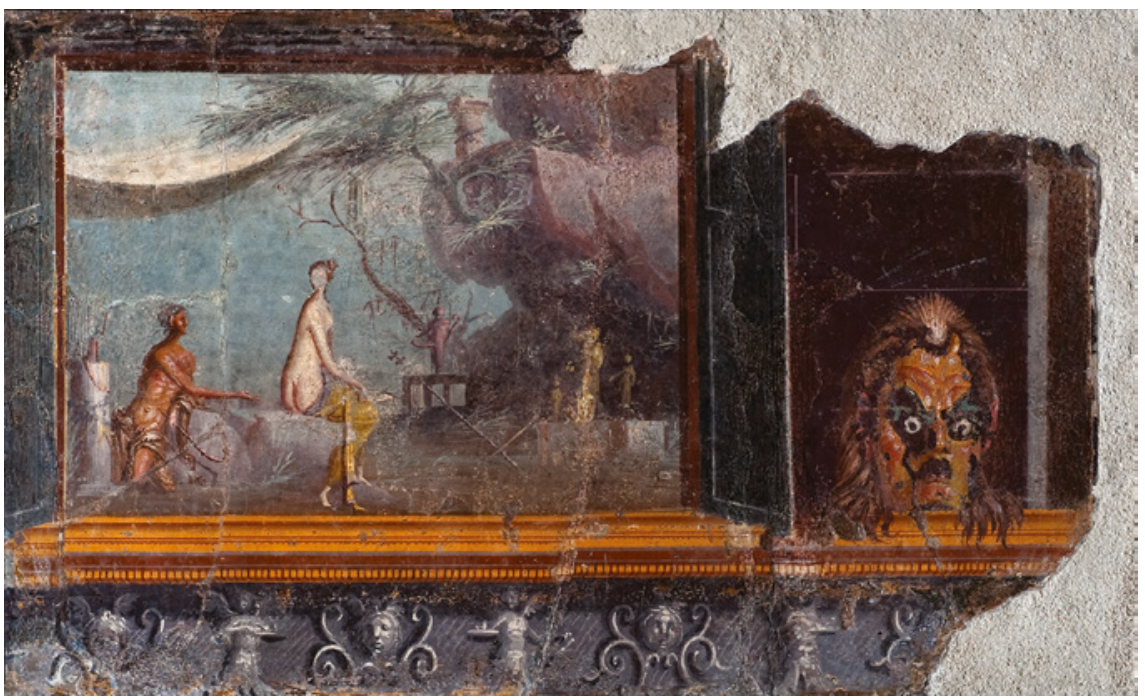

FIGURE 17.7 Unprovenanced panel from Herculaneum, MN9244

PHOTO BY CONCESSION OF THE MINISTERO PER I BENI E LE ATTIVITÀ CULTURALI E PER IL TURISMO - MUSEO ARCHEOLOGICO NAZIONALE DI NAPOLI

With this in mind, it is noteworthy that Leach identifies a cave in the top righthand corner of the Boscotrecase panel (fig. 17.1). ${ }^{24}$ As this panel has seen both damage and restoration, it is difficult to be sure if a cave is really depicted here. A further rocky structure can certainly be seen in this area of the painting, which forms an arched roof, as one would expect of a cavern. The wear here makes it unclear if the darkness is the mouth of a recess or, instead, just the damaged painted surface; however, the rocks and the brushstrokes do seem to angle inwards, as if receding into the mountainside. If the cave is indeed depicted here - and I am inclined to agree with Leach that it is - it is striking that the artist has specifically chosen this feature to provide the background for the miniature allusion to Homer's epic in this painting. Another example, an unprovenanced panel from Herculaneum (MNN9244; fig. 17.7), also alludes to the cave. We see motifs, familiar from idyllic landscape panels such as Boscotrecase Red Room (fig. 17.2) - including cult statues and an aniconic

24 E.W. Leach, 'Polyphemus in a landscape: Traditions of pastoral courtship', in. J.D. Hunt (ed.), The Pastoral Landscape (Washington 1992), 62-87, esp. 71; E.W. Leach, 'Satyrs and spectators: Reflections of theatrical settings in third style mythological continuous narrative painting', in D. Scagliarini Corlàita (ed.), I temi figurativi nella pittura parietale antica (IV sec. a.C. $-I V$ sec. d.C.) (Bologna 1997), 81-85, esp. 81. 
column - but here the landscape again recedes into darkness, as if a cavernous opening in the rockface. The darkness of the cave is not only intimidating and wild but also evocative of the epic undertones present in Polyphemus' tradition, which here loom over the pastoral iconography.

We have seen, therefore, that the landscape and the representational tradition, invoked by Bergmann's "rhythms of recognition", establish a pastoral idealism in the Polyphemus paintings; however, this idyllic atmosphere is constantly undermined by numinous and epic landscape references. This may be a pastoral love story, but it is one that sits in the shadow of the epic cave and the violence that unfolds there.

\section{3}

An Elemental Affair

Polyphemus, depicted on his rocky terrain, acts as a landscape counterpart to the seascape inhabited by Galatea and many of the Polyphemus panels make a point of this juxtaposition. For example, in the roundel painting from the Casa dei Vasi di Vetro (fig. 17.8), the boundary line between land and sea cuts a geometric, and rather jarring dividing line across the circle. In two other examples, the water occupies a more dominant part of the panel: in the peristyle of the Casa della Caccia Antica (fig. 17.9), the sea takes a central position and in the painting from the Casa dei Capitelli Colorati (fig. 17.10), it flows diagonally across the panel. In both images, therefore, the Cyclops is pushed not only to the edge of his landscape - in his longing for the sea - but also, visually, to the periphery of the painting itself. This land/sea divide is explicitly teased in the panel, from Rome, depicting Polyphemus attempting to swim to Galatea. In this painting he is shown literally reined and guided into the sea by love in the form of Cupid, an act that receives only mockery from the spectating sea-nymphs.

In the panels showing Polyphemus with a letter (such as fig. 17.11), however, the land/sea divide becomes more than just a matter of habitat. It is somewhat unexpected to see the Cyclops in written correspondence with Galatea, when his courtship is traditionally enacted in a vocalised song. I propose here that the act of sending a love letter, via Cupid, across an insurmountable physical barrier frames Polyphemus in a paraklausithyron. ${ }^{25}$ Whilst the locked-outlover of a paraklausithyron is usually barred from his beloved by the physical barrier of a door, Polyphemus is instead a victim of the landscape. Nowhere

25 Since the preparation of this chapter, Valladares has also published on this theme, $\mathrm{H}$. Valladares, Painting, Poetry, and the Invention of Tenderness in the Early Roman Empire (Cambridge, 2020), 121-128. 


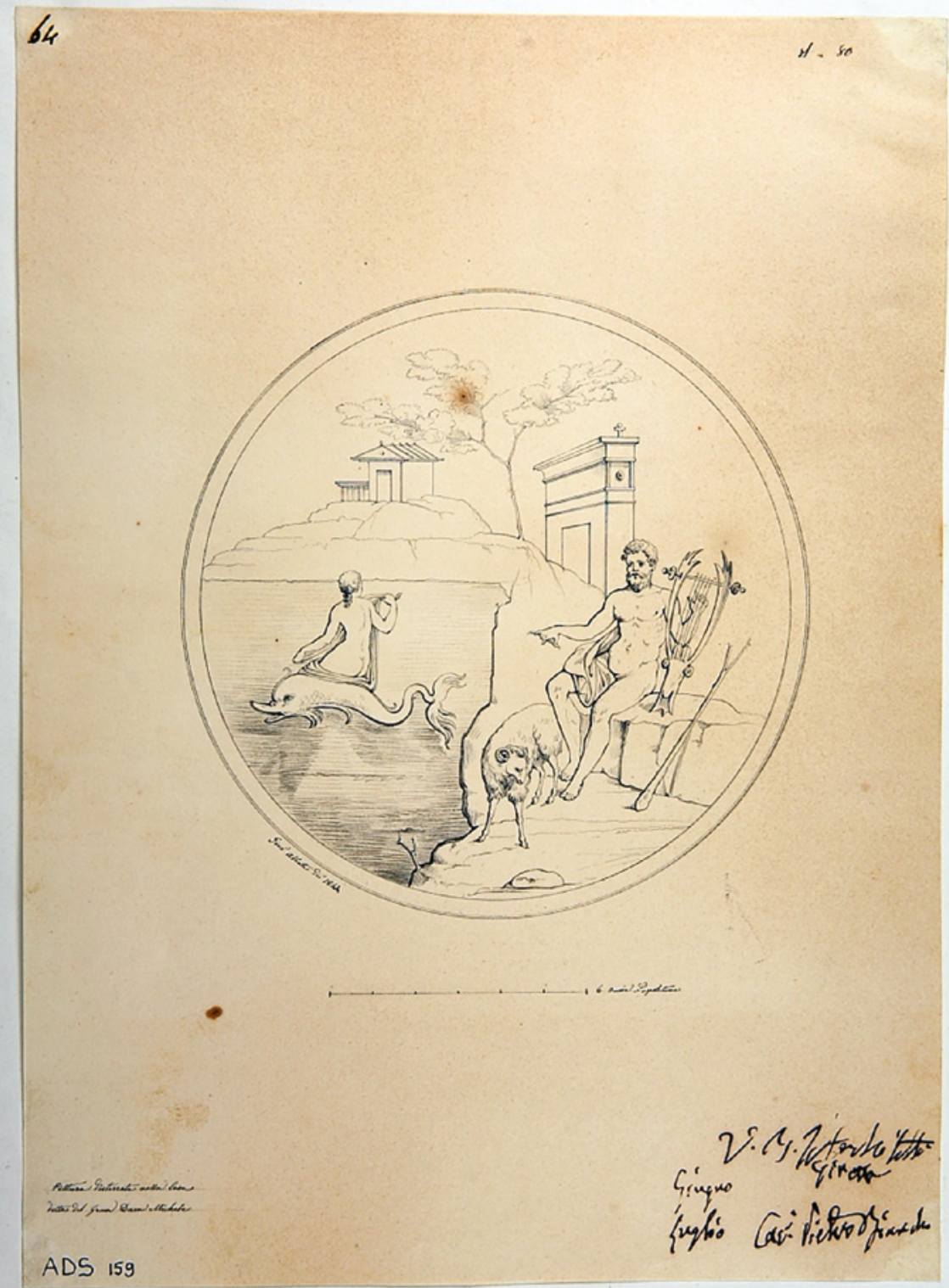

FIGURE 17.8 Panel from the Casa dei Vasi di Vetro

PHOTO BY CONCESSION OF THE MINISTERO PER I BENI E LE ATTIVITÀ CULTURALI E PER IL TURISMO - MUSEO ARCHEOLOGICO NAZIONALE DI NAPOLI 


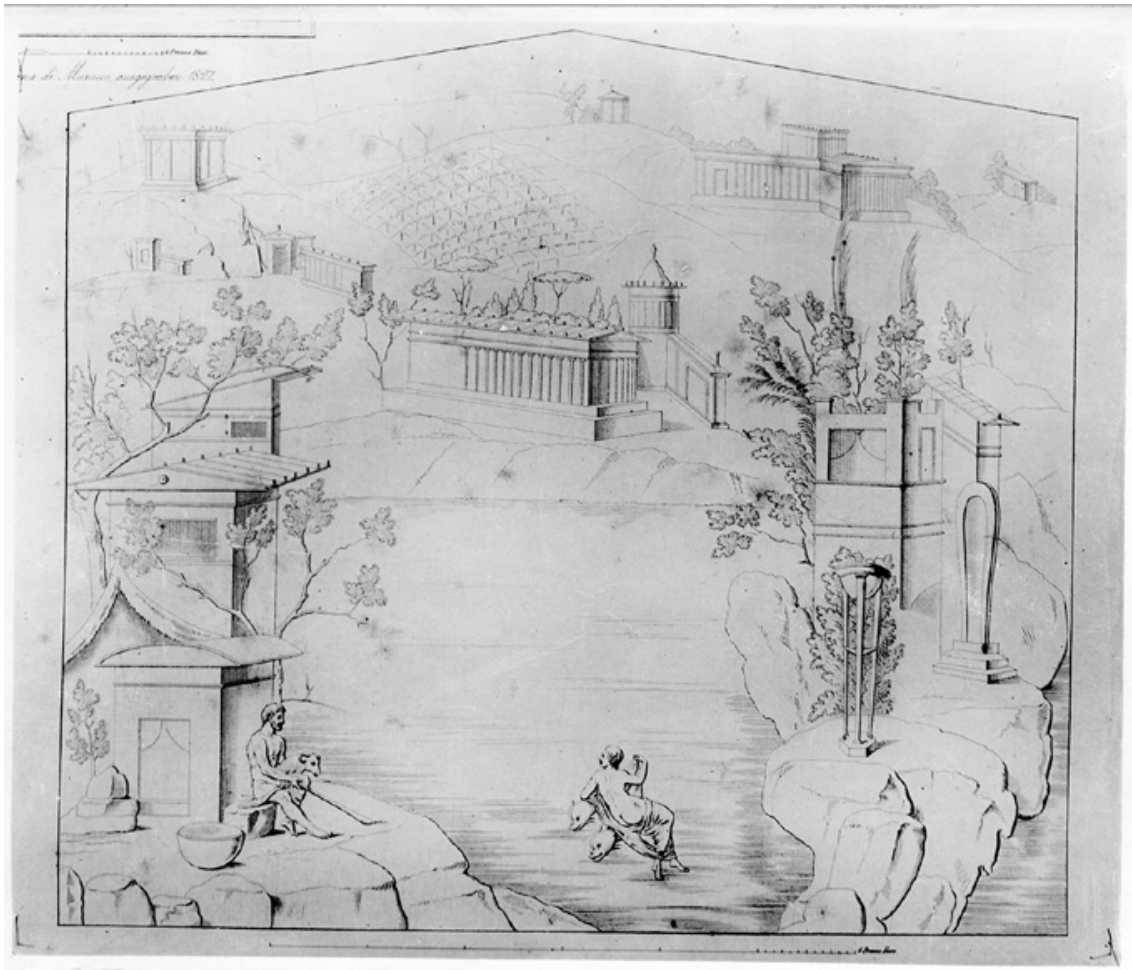

FIGURE 17.9 Panel from the Casa di Caccia Antica

PHOTO COURTESY OF PROFESSOR MICHAEL SQUIRE

in Polyphemus' extant literary tradition do the lovers communicate by letter, so the allusion to epistolary courtship makes a particular display of the lovers' physical, elemental, separation. ${ }^{26}$ DuQuesnay, in discussion of Theocritus, describes Idyll 11 as a Greek komos, which he notes is "also called the paraclausithyron or song of the locked-out-lover."27 More specifically, he argues for the landscape's role in the formation of the genre's necessary threshold: "The setting is again the countryside and more specifically, the sea-shore. The former serves to reinforce Polyphemus' rusticity; the latter acts as a witty substitute for the threshold of the beloved's house in the conventional urban kosmos."28

26 In Theoc. 6.31-32, the author does mention that Galatea might send him a messenger, but this is merely hypothetical.

27 I. DuQuesnay, 'From Polyphemus to Corydon:Virgil, Eclogue 2 and the Idylls of Theocritus', in D. West and T. Woodman (eds.), Creative Imitation and Latin Literature (Cambridge 1979), 45 .

28 DuQuesnay 1979, op. cit. (n. 26), 46. 


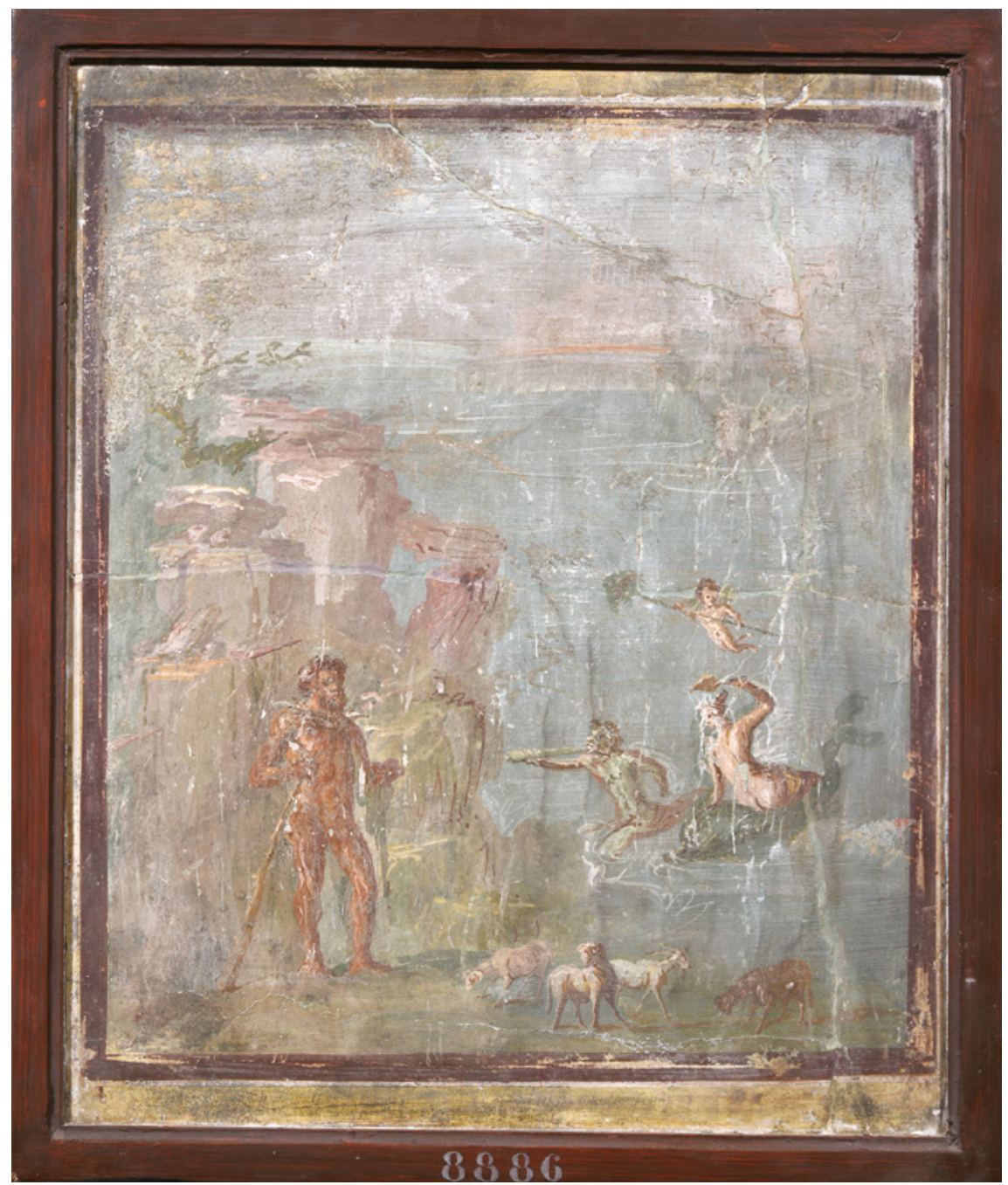

FIGURE 17.10 Panel from the Casa dei Capitelli Colorati

PHOTO BY CONCESSION OF THE MINISTERO PER I BENI E LE ATTIVITÀ CULTURALI E PER IL TURISMO - MUSEO ARCHEOLOGICO NAZIONALE DI NAPOLI

By the first century CE, the locked-out-lover belongs in a generic tradition which explicitly engages with the writing of love letters as depicted in these paintings: Roman love elegy. ${ }^{29}$ Indeed, Simon reads these Polyphemus paint-

29 See S.H. Lindheim, Mail and Female: Epistolary Narrative and Desire in Ovid's Heroides (Madison 2003), 16-17 and see 81 where she notes that desire is evoked in the Heroides "both by the metrical form of these poems (elegy) and by their content (love affairs)." 
ings, and the use of Cupid as a "postman", through the lens of Ovid's epistolary elegiac poetry, the Heroides: "In Ovids Heroides existiert zwar kein Brief der Galatea an Polyphem, doch Amor als „Postbote" lässt sich durch jenes Jugendwerk Ovids besser verstehen."30

The depiction of letter writing both emphasises the distance between lover and beloved, which is key to the locked-out-lover, and alludes to the genre, namely elegy, particularly suited to this figure. The intention here is not to suggest that these paintings aimed to illustrate an elegiac text, but instead that the motif had certain contemporary associations which frame the Cyclops in a paraklausithyron. His separation, however, is one caused not by the house but rather by the landscape; he sits on the threshold of land and sea and, therefore, underscores his own elemental incompatibility with the nymph.

Further to this elemental incompatibility, the pair's bodies also echo the respective landscapes to which they are both bound. Even as far back as Homer, the Cyclops is described as a "wooded mountain peak"31 (Od. 9.191192) and this persists through to Philostratus where he is "a mountainous and terrible being" (Im. 2.18.3). ${ }^{32}$ Just as the poets conceived of Polyphemus as an embodiment of his landscape, the Campanian wall-paintings depict him as dark in colour and solid with muscle, like the threatening and rigid mountain upon which he sits. This is especially felt in images where the Cyclops sits directly in front of his mountainous landscape (such as Boscotrecase [fig. 17.1] and the Casa del Sacerdos Amandus [fig. 17.4]), and the contours of his body mirror the contours of the rigid, angular rocks behind him. This is nicely exemplified by the letter panel from Herculaneum (fig. 17.11) where the curve of Polyphemus' body echoes the curve of the mountainside. In addition, Polyphemus' bushy and untamed hair in many of the panels (such as panel MNN8983 from Herculaneum, and the panels from the Casa del Sacerdos Amandus, Boscotrecase, Casa 5.2,d, the Caupona della Via di Mercurio, the Casa delle Pareti Rosse, and the letter panel from the Casa di Marcus Lucretius) also reflect the conceptualisation of Polyphemus as a "wooded mountain peak": his hair is like the shady forest on top of his muscular, mountainous body. The comparison between thick bristly hair and foliage is one that Polyphemus makes himself in Ovid's Metamorphoses. He boasts about his coma (13.844),

See as well M.O. Drinkwater, 'Which letter? Text and subtext in Ovid's Heroides', AJPh 128 (2007), 367-387, esp. 368 , where he states that " $[t]$ he importance of letters in elegiac seduction is well evidenced."

$30 \quad$ E. Simon, 'Ovid und Pompeji', Thetis 13-14 (2007), 149-154, esp. 151.

31 Translation: A. Sharrock, 'Representing metamorphosis', in J. Elsner (ed.), Art and Text in Roman Culture (Cambridge 1996), 103-130, esp. 129.

Translation: Squire 2009, op. cit. (n. 7), 344. 


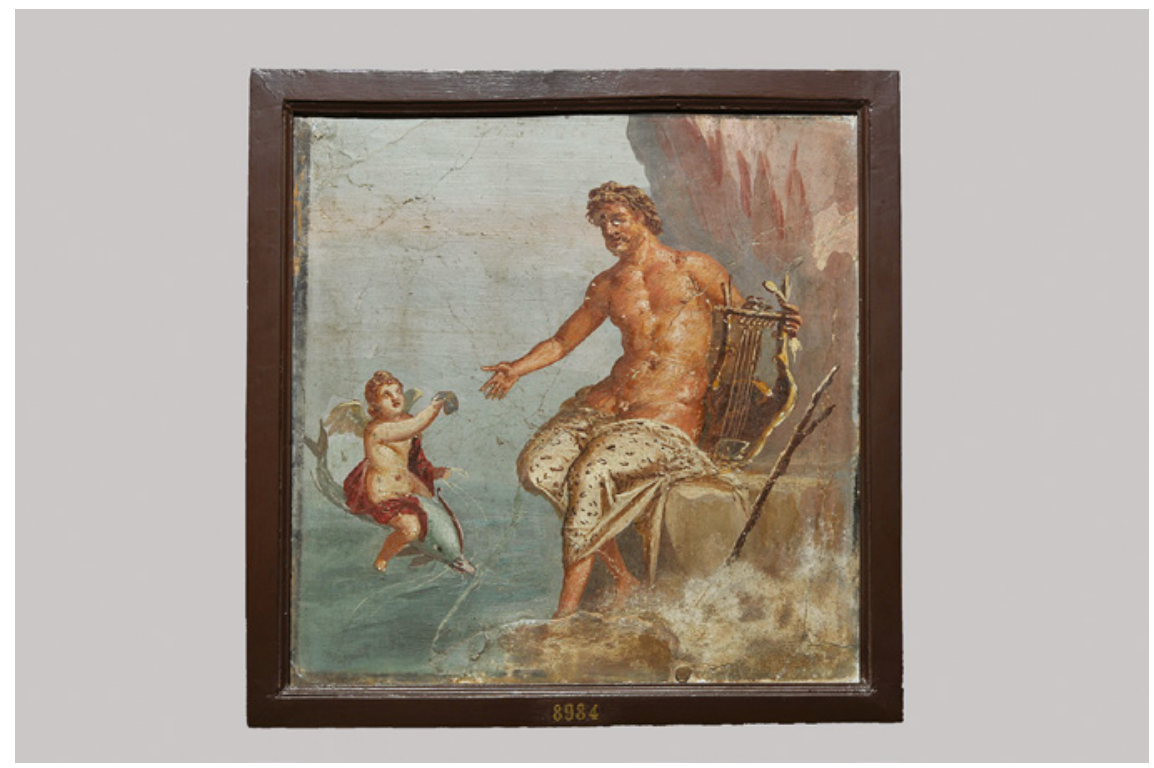

FIGURE 17.11 Unprovenanced panel from Herculaneum, MN8984

PHOTO BY CONCESSION OF THE MINISTERO PER I BENI E LE ATTIVITÀ CULTURALI E PER IL TURISMO - MUSEO ARCHEOLOGICO NAZIONALE DI NAPOLI

providing shade for his body, which is densissimum (13.846) with bristles, both of which are words that can be used of foliage too. ${ }^{33}$

The rigidity and solidity of Polyphemus' body and bristling of his hair are juxtaposed, then, with the softer features of Galatea's feminine physique. Her iconography here is typical of sea-nymph representation elsewhere in Roman art and, as such, her depiction is inherently intertwined with marine landscapes. Furthermore, her body and posture also allude to the sea. The Boscotrecase (fig. 17.1) and Sacerdos Amandus panels (fig. 17.4) nicely exemplify this: Galatea has a soft and fleshy body which undulates like the sea on which she floats, and her drapery flows around her, blown, like the surrounding waves, by the breeze. The pair embody the landscapes which they inhabit, and which are themselves physically distinct. This is no ordinary pastoral or elegiac courtship, but it is one that has elemental, perhaps even cosmic, implications.

The land/sea divide, however, has further consequences in the context of Polyphemus' part-Cyclopean/part-Olympian lineage, a juxtaposition which 
further illustrates the generic interplay at stake in his representation. The Cyclopes, in various mythological accounts, were a race closely aligned with the idealised, and labour-free, rural life of the Golden Age (see, for example, Od. 9.105-111). We have already seen how idealised landscapes were linked with pastoral poetry, but the Cyclopean life was also evocative of the utopian Golden Age, praised most famously by Virgil's fourth Eclogue and associated with pastoral landscape idealisation. Moreover, Homer describes the race as being land-bound, with, he says, "no red-sided ships, nor any men, as naval carpenters, who could work on well-benched ships for them." ${ }^{34}$ It is perhaps ironic, therefore, that Polyphemus - himself one of the Cyclopes - was also the son of the king of the sea, Poseidon, who is heavily involved in the Odyssey's epic narrative. Whilst Polyphemus is unable to follow Odysseus' ship into the sea himself, he can still take advantage of his Olympian lineage and it is Poseidon who enacts the Cyclops' curse and plagues Odysseus' nostos in the epic. His elemental inability to cross over into the sea is therefore not just a lover's issue but also an irony of his lineage and at stake in his generic duality.

This clash of land and sea in the genre and heritage of Polyphemus is exploited in the paintings themselves, such as the one from the Casa del Sacerdos Amandus (fig. 17.4). Here, the idealised rural world is evoked by Polyphemus' pastoral attributes and landscape; yet the looming image of a ship floating on the sea in the background is enough to threaten the arrival of the epic hero. This clash is also well illustrated by the epic panel from the Casa di Laocoonte (fig. 17.5). The ship looms large in the very centre of this image, with a foreshortened prow that appears to penetrate both the panel and the landscape in its foreground. Polyphemus stands in the front and is shown in a decidedly pastoral guise, with his shepherd's staff, his flock, and his panpipes hung conspicuously around his neck. The ship, therefore, appears as a domineering penetration into Polyphemus' pastoral (ship-less) life.

Through this land/sea divide, therefore, the landscape of Polyphemus engages with the duality and ambiguity that is implicit in his heritage and hopeless infatuation. It undermines the simple, pastoral idealism of the narrative with something far more elemental and epic in both scale and genre. 
My paper has looked at the representation of landscape in the myth of Polyphemus from two main angles. I first discussed how parallels with idyllic, non-narrative, paintings were juxtaposed with Polyphemus' epic narrative and threatening cave. The second part of my paper then looked more specifically at the elemental and ancestral divide established through the distinction between land and sea. Both of these angles attempted to exemplify how landscape could be used, in a more specific way, as a tool of representation and as a way of playing with the character of Polyphemus and his mythical, literary, and visual tradition.

I will now close with some thoughts on how this may reflect more broadly on the Roman idea of landscape in the early Empire. It should be noted that this period saw an influx of iconographical inspiration from the Hellenistic world, which inspired innovation in the visual arts, including landscape representation. More specifically, though, the villa environment and its management and construction of the countryside, which evolved in the first centuries BCE/CE, also encouraged reflection on the relationship between the natural world and artificiality, which is key to (and expressed through) painted landscape representation. Within this visual cultural environment, therefore, the potential for landscape to provide more than just atmospheric, natural background was potent. Landscape representation, we have seen, was an active participant in the viewer's interpretation of and interaction with the tradition of Polyphemus in Campanian wall-painting. More than this, however, it was also a platform on which the implications of representing the landscape could be considered, used, and challenged; it could reflect the ambiguity of Polyphemus' own representational tradition; it could conjure up a discourse on various literary genres within the visual medium; and it could consciously play with the expectations and knowledge of the viewer. 


\begin{tabular}{|c|c|c|c|c|c|c|}
\hline Subject & Town/Villa & Chronology & House no. & Casa ... & Room & $\begin{array}{l}\text { Accession } \\
\text { no. (where } \\
\text { applicable) }\end{array}$ \\
\hline $\begin{array}{l}\text { Polyphemus and } \\
\text { Galatea }\end{array}$ & Pompeii & Third Style $^{a}$ & $1.1,7$ & $\begin{array}{l}\text { del Sacerdos } \\
\text { Amandus }\end{array}$ & (b) & \\
\hline $\begin{array}{l}\text { Polyphemus send- } \\
\text { ing a letter }\end{array}$ & Pompeii & Fourth Style & $5 \cdot 2, \mathrm{~d}$ & Unnamed & $(\mathrm{m})$ & \\
\hline $\begin{array}{l}\text { Polyphemus and } \\
\text { Galatea }\end{array}$ & Pompeii & Fourth Style & $6.5,5$ & $\begin{array}{l}\text { dei Vasi di } \\
\text { Vetro }\end{array}$ & $(12)$ & \\
\hline $\begin{array}{l}\text { Polyphemus send- } \\
\text { ing a letter }\end{array}$ & Pompeii & Fourth Style & $6.10,1$ & $\begin{array}{l}\text { Caupona } \\
\text { della Via di } \\
\text { Mercurio }\end{array}$ & (d) & \\
\hline $\begin{array}{l}\text { Polyphemus send- } \\
\text { ing a letter }\end{array}$ & Pompeii & Fourth Style & $6.14,28.33$ & di Laocoonte & (c) & \\
\hline $\begin{array}{l}\text { Polyphemus and a } \\
\text { hero (Aeneas?) }\end{array}$ & Pompeii & Third Style & $6.14,28.33$ & di Laocoonte & $(\mathrm{k})$ & MNN111211 \\
\hline $\begin{array}{l}\text { Polyphemus and } \\
\text { Galatea }\end{array}$ & Pompeii & Third Style & $7 \cdot 4,31.5^{1}$ & $\begin{array}{l}\text { dei Capitelli } \\
\text { Colorati }\end{array}$ & $(26)$ & MNN8886 \\
\hline $\begin{array}{l}\text { Polyphemus and } \\
\text { Galatea in erotic } \\
\text { embrace }\end{array}$ & Pompeii & Fourth Style & $7 \cdot 4,48$ & $\begin{array}{l}\text { della Caccia } \\
\text { Antica }\end{array}$ & $(15)$ & MNN27687 \\
\hline $\begin{array}{l}\text { Polyphemus and } \\
\text { Galatea }\end{array}$ & Pompeii & Fourth Style & $7 \cdot 4,48$ & $\begin{array}{l}\text { della Caccia } \\
\text { Antica }\end{array}$ & (13) & \\
\hline $\begin{array}{l}\text { Polyphemus and } \\
\text { Galatea }\end{array}$ & Pompeii & Third Style & $7 \cdot 15,2$ & del Marinaio & $\left(z^{\prime}\right)$ & \\
\hline $\begin{array}{l}\text { Polyphemus and } \\
\text { Galatea in erotic } \\
\text { embrace }\end{array}$ & Pompeii & Fourth Style & $8.5,37$ & $\begin{array}{l}\text { delle Pareti } \\
\text { Rosse }\end{array}$ & (b) & \\
\hline $\begin{array}{l}\text { Polyphemus and } \\
\text { Galatea in erotic } \\
\text { embrace }\end{array}$ & Pompeii & Fourth Style & $9 \cdot 2,10$ & del Gallo II & (g) & \\
\hline $\begin{array}{l}\text { Polyphemus and } \\
\text { Galatea }\end{array}$ & Pompeii & Fourth Style & $9 \cdot 3,5 \cdot 24$ & $\begin{array}{l}\text { di Marcus } \\
\text { Lucretius }\end{array}$ & (5) & \\
\hline $\begin{array}{l}\text { Polyphemus send- } \\
\text { ing a letter }\end{array}$ & Pompeii & Fourth Style & $9 \cdot 3,5 \cdot 24$ & $\begin{array}{l}\text { di Marcus } \\
\text { Lucretius }\end{array}$ & (7) & \\
\hline $\begin{array}{l}\text { Polyphemus and } \\
\text { Galatea }\end{array}$ & Pompeii & Third Style & 9.6,d-e & $\begin{array}{l}\text { di Dido ed } \\
\text { Aeneas }\end{array}$ & (c) & \\
\hline
\end{tabular}


(cont.)

\begin{tabular}{|c|c|c|c|c|c|c|}
\hline Subject & Town/Villa & Chronology & House no. & Casa ... & Room & $\begin{array}{l}\text { Accession } \\
\text { no. (where } \\
\text { applicable) }\end{array}$ \\
\hline $\begin{array}{l}\text { Polyphemus and } \\
\text { Galatea }\end{array}$ & Pompeii & Third Style & $9 \cdot 7,12$ & Unnamed & (5) & \\
\hline $\begin{array}{l}\text { Polyphemus send- } \\
\text { ing a letter }\end{array}$ & Herculaneum & Fourth Style & unknown & unknown & unknown & MNN8984 \\
\hline $\begin{array}{l}\text { Polyphemus and } \\
\text { two women }\end{array}$ & Herculaneum & $\begin{array}{l}\text { Possibly } \\
\text { Fourth Style }\end{array}$ & unknown & unknown & unknown & MNN8983 \\
\hline $\begin{array}{l}\text { Polyphemus and } \\
\text { Galatea }\end{array}$ & Herculaneum & $\begin{array}{l}\text { Possibly } \\
\text { Fourth Style }\end{array}$ & unknown & unknown & unknown & MNN9244 \\
\hline $\begin{array}{l}\text { Polyphemus swim- } \\
\text { ming to Galatea }\end{array}$ & $\begin{array}{l}\text { Palatine, } \\
\text { Rome }\end{array}$ & Second Style ${ }^{c}$ & $\mathrm{~N} / \mathrm{A}$ & di Livia & tablinum & \\
\hline $\begin{array}{l}\text { Polyphemus and } \\
\text { Galatea }\end{array}$ & $\begin{array}{l}\text { Villa at } \\
\text { Boscotrecase }\end{array}$ & Third Style & $\mathrm{N} / \mathrm{A}$ & $\mathrm{N} / \mathrm{A}$ & (19) & 20.192 .17 \\
\hline $\begin{array}{l}\text { Polyphemus and } \\
\text { Galatea, depicted } \\
\text { as masks }\end{array}$ & $\begin{array}{l}\text { Assisi, } \\
\text { Umbria }\end{array}$ & Third Style & $\mathrm{N} / \mathrm{A}$ & di Properzio & $\begin{array}{l}\text { crypto- } \\
\text { porticus }\end{array}$ & \\
\hline
\end{tabular}

c Second Style: approximately early to late first century BCE 